\title{
OS MOMENTOS PROBATÓRIOS NO DIREITO PROCESSUAL PENAL
}

\author{
THE MOMENTS EVIDENCE IN CRIMINAL PROCEDURAL LAW
}

Fabiano Yuji Takayanagi*

\begin{abstract}
Resumo:
No Processo Penal, a valoração da prova é um direito no qual as partes se utilizam para que suas teses defensivas e contrapostas sejam devidamente apreciadas pelo juiz e este, por sua vez, decidirá. Destarte, os momentos probatórios no processo penal têm suma importância para que se tenha um norte traçado e trilhos a serem seguidos ao longo de toda busca e produção de provas. Por essa razão, o presente estudo tem o fito de demonstrar passo a passo esse caminho probatório tão essencial.

Palavras chaves: Investigação. Propositura. Admissão. Produção. Valoração.
\end{abstract}

\begin{abstract}
:
In criminal proceedings, evidence rules consist in a right by which the parties use their theses opposing defensive and are duly appreciated by the judge and this, in turn, will decide. Thus, evidence in criminal proceedings have paramount importance in order to have a direction and trails to be followed throughout the entire search and evidence. Therefore, the present study has the aim of demonstrating this procedure step by step.
\end{abstract}

Keywords: Investigation. Evidences.

\section{Introdução}

Para que uma prova seja devidamente valorada deve passar por momentos essenciais à verificação de sua legalidade e possível inclusão ao processo, motivo pelo qual os momentos probatórios são direitos que podem ser subdivididos em cinco, quais sejam: i) a investigação, ii) a propositura, iii) a admissão, iv) a produção, e v) a valoração. Assim sendo, dada à importância peculiar de cada momento probatório, serão destrinchados um a um, consoante se verifica a seguir.

\section{Investigação}

$\mathrm{O}$ primeiro momento probatório estaria conectado à busca de provas. Conforme Gustavo Badaró afirma “tal direito sempre foi reconhecido, ainda que sem

Bacharel pela Faculdade de Direito da Universidade de São Paulo. Mestrando em Direito Processual Penal pela Faculdade de Direito da Universidade de São Paulo, sob orientação do Professor Maurício Zanoide de Moraes. Advogado criminal. (http://lattes.cnpq.br/6167726843402233) 
preocupação de estudá-lo sistematicamente, ao Ministério Público e ao acusador privado, sendo exercido, principalmente, por meio do inquérito policial". ${ }^{1}$

Todavia, o inquérito policial não é a regra, há casos em que são utilizados outros meios de investigações prévios, ou pelo fato da materialidade e da autoria delitiva se encontrarem tão evidentes que não seria necessária uma investigação. ${ }^{2}$

Em regra, para as investigações preliminares, tem-se o inquérito policial que, segundo Marta Saad, pode ser entendido como um meio pelo qual se visa apurar o fato, “que aparenta ser ilícito e típico, bem como sua autoria, coautoria e participação, é o procedimento preliminar ou prévio, cautelar, realizado pela polícia judiciária ${ }^{3}$ e, portanto, de natureza administrativa e finalidade judiciária". ${ }^{4}$

Gustavo Badaró entende que o inquérito policial seria um procedimento investigativo administrativo realizado pela polícia judiciária, "consistente em atos de investigação visando apurar a ocorrência de uma infração penal e sua autoria, a fim de que o titular da ação penal possa ingressar em juízo, bem como requerer medidas cautelares". 5

Pode-se haver a interpretação desse tipo de investigação como sendo basicamente o caminho pelo qual se busca apurar o fato ilícito e típico com atos que visem à elucidação desse fato. Assim, o inquérito seria a reunião de atos com o fito de investigação criminal, conduzido sob a forma de diligências, exames e interrogatórios, realizados pela autoridade policial, que reduz a escrito e autua, com o fim de desvendar o crime comum e descobrir seu autor.

Outros entendem ser o inquérito um preparatório da ação penal. Trata-se, "pois, de procedimento cautelar; de natureza administrativa; que contém investigação e instrução policial, acerca de fato, supostamente violante da norma penal; todas as circunstâncias que o envolvem, e respectiva autoria. O fim e o destino do inquérito são judiciários". ${ }^{6}$

Já há aqueles que defendem o inquérito policial como sendo uma forma de registro e coletas de provas do fato. Seria o registro formal, legal, e cronologicamente escrito, conduzido e elaborado por autoridade policial legitimamente incumbida para

BADARÓ, Gustavo H. R. Ivahy. Direito processual penal. Rio de Janeiro: Elsevier, 2008, t. 1. p. 204.

Neste último caso, veja-se, por exemplo, nos crimes cometidos contra a honra, quando o delito é cometido por meio da imprensa e o autor assina a matéria publicada, ora, não haveria a exigência de uma investigação para averiguar as ocorrências.

3 Cumpre esclarecer que a polícia se divide em Polícia de Segurança, que exerce a atividade preventiva e a de repressão imediata ao delito, no caso das polícias militares, e a Polícia Judiciária, que também é chamada de "repressiva", que exerce a investigação do delito, ficando a cargo da Polícia Civil dos Estados e da Polícia Federal. Ambas as Polícias são órgãos administrativos, e a denominada “judiciária" se deve a sua finalidade de atividade, uma vez que o inquérito por ela desenvolvido será a base de um possível processo penal. (BADARÓ, Gustavo H. R. Ivahy. Direito processual penal. Rio de Janeiro: Elsevier, 2008. p. 41)

4 SAAD, Marta. O direito de defesa do inquérito policial. São Paulo: Revista dos Tribunais, 2004. p. 139.

5 BADARÓ, Gustavo H. R. Ivahy. Direito processual penal. Rio de Janeiro: Elsevier, 2008. t. 1, p. 42.

6 SAAD, Marta. op. cit., p. 140-142. 
autenticar suas investigações e diligências nas apurações das infrações penais, das circunstâncias e dos autores. Seria ele composto pelas peças relativas às diligências realizadas para apuração do fato delituoso, requerimentos, autos de exames periciais, termos de declarações, depoimentos, etc.

Por fim, como bem explicita Marta Saad, existem os que consideram o inquérito policial como sendo um "procedimento técnico-jurídico, formal e escrito, elaborado pela policia judiciária, enfeixando a coleta dos elementos materiais probatórios das infrações penais, de suas circunstâncias e a identificação dos seus autores, para auxiliar o Poder Judiciário na realização da justiça penal, bem como para a concretização de providências cautelares no interesse da ordem pública".?

Mirabete ensina, por sua vez, que é "todo procedimento policial destinado a reunir os elementos necessários à apuração da prática da infração penal e de sua autoria. Trata-se de uma instrução provisória, preparatória, informativa, em que se colhem elementos por vezes difíceis de obter na instrução judiciária, como auto em flagrante, exames periciais etc. Seu destinatário imediato é o Ministério Público ou o ofendido, que com ele formam sua opinio delicti para a propositura da denúncia ou queixa. $\mathrm{O}$ destinatário mediato é o Juiz, que nele também pode encontrar fundamentos para julgar". ${ }^{8}$ Cabe esclarecer que tal procedimento não é indispensável para a propositura da ação penal.

A finalidade do inquérito policial está instituída no art. $4^{\circ}$ do Código de Processo Penal como sendo a apuração da existência da infração e a respectiva autoria e servirá de base para o Ministério Público, ou o querelante, para que forme a sua opinio delicti e dê o embasamento probatório suficiente para que ação penal tenha justa causa.

Sendo assim, tal momento probatório é de evidente importância pelo fato de buscar elementos necessários para fundamentar uma possível ação penal, bem como para corroborar a sua inexistência.

\subsection{Outras formas de investigação preliminares (ou inquéritos extrapoliciais) ${ }^{9}$}

Consoante já explanado, não há somente o inquérito policial para as investigações preliminares, há, ainda, outras formas de averiguações como o inquérito policial militar, as comissões parlamentares de inquérito - CPI's (Lei. n. 1.579/52), inquérito administrativo em sentido estrito, o extinto inquérito judicial do Decreto-Lei n. 7.661/45, o inquérito policial do Código Florestal (Lei n. 4.771/65).

SAAD, Marta. op. cit., p. 143.

MIRABETE, Julio Fabrini. Processo penal. 18. ed. São Paulo: Atlas, 2008. p. 60.

Há melhor exemplificação em BADARÓ, Gustavo H. R. Ivahy. Direito processual penal. Rio de Janeiro: Elsevier, 2008. t. 1, p. 43; e SAAD, Marta. O direito de defesa do inquérito policial. São Paulo: Revista dos Tribunais, 2004. p. 98-128. 
São, por conseguinte, outras maneiras de se buscar elementos informativos para se fundamentar uma eventual ação penal. Veja-se o exemplo dos inquéritos parlamentares: não são instaurados para a busca exclusivamente penal, mas, sim, para investigação de fatos politicamente relevantes e reprováveis e, nessa averiguação, caso haja a descoberta de eventual delito, o relatório do que foi apurado é enviado ao Ministério Público para que tome as providências cabíveis.

Assim, as CPI's não têm a finalidade precípua de investigação penal, mas têm amplos poderes de atuação como se interpreta pela leitura do art. $2^{\circ}$ da Lei n. 1.579/52, que aduz: "No exercício de suas atribuições, poderão as Comissões Parlamentares de Inquérito determinar as diligências que reportarem necessárias e requerer a convocação de Ministros de Estado, tomar o depoimento de quaisquer autoridades federais, estaduais ou municipais, ouvir os indiciados, inquirir testemunhas sob compromisso, requisitar de repartições públicas e autárquicas informações e documentos, e transportar-se aos lugares onde se fizer mister a sua presença". ${ }^{10}$

10 Cabe salientar que embora as Comissões Parlamentares de Inquérito estarem revestidas por poderes investigatórios constitucionalmente garantidos nos termos do art. 58, parágrafo terceiro, da Constituição Federal ("As comissões parlamentares de inquérito, que terão poderes de investigação próprios das autoridades judiciais, além de outros previstos nos regimentos das respectivas Casas, serão criadas pela Câmara dos Deputados e pelo Senado Federal, em conjunto ou separadamente, mediante requerimento de um terço de seus membros, para a apuração de fato determinado e por prazo certo, sendo suas conclusões, se for o caso, encaminhadas ao Ministério Público, para que promova a responsabilidade civil ou criminal dos infratores"), sua atuação não é ampla e descomedida. Dessa forma, apesar das CPI's serem constitucionalmente protegidas em sua atuação investigatória, não podem atuar indiscriminadamente em todos os Poderes além de sua esfera de ação. Isso se deve ao fato da existência da já conhecida e defendida pelo Supremo Tribunal Federal "reserva de jurisdição", isto é, casos em que a função jurisdicional somente pode ser exercida por integrantes do Poder Judiciário, que diante de um conflito de interesses, estariam os magistrados mais bem preparados para resolvê-los já que revestidos de garantias (vitaliciedade, inamovibilidade, irredutibilidade de subsídios e a possibilidade de arguição de incompatibilidade) que proporcionam a imparcialidade no julgamento na tentativa de alcançar um resultado mais próximo do socialmente justo. Por exemplo, não pode uma Comissão Parlamentar de Inquérito invadir um domicílio alheio para realizar busca e apreensão no período diurno sem um mandado judicial, tampouco pode decretar a quebra de sigilo de dados simplesmente a bel prazer da investigação, há a necessidade de autorização judicial. Veja-se pelos julgados colacionados da Corte Máxima Brasileira: "Habeas Corpus. Formação de quadrilha visando à prática de crimes contra o INSS. Denúncia baseada, entre outros elementos, em provas coletadas por meio de busca e apreensão domiciliar ordenada por Comissão Parlamentar de Inquérito, em decisão não fundamentada, o que tem sido repelido por esta Corte (Mandados de Segurança n.s 23.452, 23.454, 23.619 e 23.661, entre outros). Denúncia que aponta a materialidade do delito, bem como indícios de autoria fortemente demonstrados por outros documentos, testemunhos e elementos carreados pelo Ministério Público. Inépcia da peça acusatória não configurada. Ordem concedida em parte, para o efeito de excluir os papéis que foram objeto da busca e apreensão irregular." (HC 80.420, Rel. Min. Ellen Gracie, julgamento em 28-6-01, $1^{\circ}$ Turma, DJ de 012-02); "Incompetência da Comissão Parlamentar de Inquérito para expedir decreto de indisponibilidade de bens de particular, que não é medida de instrução - a cujo âmbito se restringem os poderes de autoridade judicial a elas conferidos no art. $58, \S 3^{\circ}$ - mas de provimento cautelar de eventual sentença futura, que só pode caber ao Juiz competente para proferi-la. Quebra ou transferência de sigilos bancário, fiscal e de registros telefônicos que, ainda quando se admita, em tese, susceptível de ser objeto de decreto de CPI porque não coberta pela reserva absoluta de jurisdição que resguarda outras garantias constitucionais -, há de ser adequadamente fundamentada: aplicação no exercício pela CPI dos poderes instrutórios das autoridades judiciárias da exigência de motivação do art. 93, IX, da Constituição da República." (MS 23.466, Rel. 
Outro exemplo de investigação extrapolicial é o inquérito administrativo em sentido estrito, utilizado pela Administração Pública, que pode ser disciplinar ou não, sendo que, no primeiro caso, visa à apuração da responsabilidade do servidor público e, no segundo caso, "envolvem pleitos dos administrados ou aplicação a eles de penalidades administrativas." 11

Caso, no decorrer dessa investigação, seja descoberto qualquer ilícito administrativo e igualmente corresponder a um ilícito penal, a autoridade administrativa tem o dever, no exercício de sua função, de comunicar à autoridade competente para que esta tome as medidas cabíveis, assim, pode-se citar a sindicância ${ }^{12}$ e o inquérito civil ${ }^{13}$ como formas preliminares de investigação extrapoliciais, que podem servir, ao mesmo tempo, no fornecimento de elementos de informação para a formação da justa causa do dominus litis no eventual oferecimento de uma denúncia.

Min. Sepúlveda Pertence, julgamento em 4-5-00, Plenário, D $J$ de 6-4-01). No mesmo sentido: MS 23.471, Rel. Min. Octavio Gallotti, julgamento em 10-11-99, Plenário, $D J$ de 10-8-00; "O sigilo bancário, o sigilo fiscal e o sigilo telefônico (sigilo este que incide sobre os dados/registros telefônicos e que não se identifica com a inviolabilidade das comunicações telefônicas) - ainda que representem projeções específicas do direito à intimidade, fundado no art. $5^{\circ}, \mathrm{X}$, da Carta Política - não se revelam oponíveis, em nosso sistema jurídico, às Comissões Parlamentares de Inquérito, eis que o ato que lhes decreta a quebra traduz natural derivação dos poderes de investigação que foram conferidos, pela própria Constituição da República, aos órgãos de investigação parlamentar. As Comissões Parlamentares de Inquérito, no entanto, para decretarem, legitimamente, por autoridade própria, a quebra do sigilo bancário, do sigilo fiscal e/ou do sigilo telefônico, relativamente a pessoas por elas investigadas, devem demonstrar, a partir de meros indícios, a existência concreta de causa provável que legitime a medida excepcional (ruptura da esfera de intimidade de quem se acha sob investigação), justificando a necessidade de sua efetivação no procedimento de ampla investigação dos fatos determinados que deram causa à instauração do inquérito parlamentar, sem prejuízo de ulterior controle jurisdicional dos atos em referência (CF, art. $5^{\circ}$, XXXV).” (MS 23.452, Rel. Min. Celso de Mello, julgamento em 16-9-99, Plenário, $D J$ de 12-5-00). Sobre o tema "reserva de jurisdição" e as Comissões Parlamentares de Inquérito, vide VILARES, Fernanda Regina. A reserva de jurisdição no processo penal: dos reflexos no inquérito parlamentar. 2010. Dissertação (Mestrado) - Faculdade de Direito. Universidade de São Paulo, São Paulo.

11 SAAD, Marta. op. cit., p. 105.

12 A sindicância constitui em uma espécie de "processo administrativo sumário para apurar irregularidade ou fato nocivo ao interesse público" e visa colher dados informativos sobre determinada matéria a ser averiguada (HORCAIO, Ivan. Dicionário jurídico referenciado. São Paulo: Primeira Impressão, 2006. p. 992).

13 O inquérito civil é uma investigação administrativa constitucionalmente prevista (Art. 129, III, da Constituição Federal: "São funções institucionais do Ministério Público: (...) III - promover o inquérito civil e a ação civil pública, para a proteção do patrimônio público e social, do meio ambiente e de outros interesses difusos e coletivos"), cujo presidente é o Ministério Público e com objetivo precípuo de colher elementos de convicção para a possível propositura de ação civil pública. Segundo Hugo Nigro Mazzilli, "o inquérito civil presta-se não só a apurar lesões a interesses difusos, coletivos e individuais homogêneos, como também, por analogia, a colher elementos preparatórios para a instrução de qualquer ação judicial de iniciativa do Ministério Público" (MAZZILLI, Hugo Nigro. A defesa dos interesses difusos em juizo. 22. ed. São Paulo: Saraiva, 2009. p. 450. Nesse mesmo sentido: LEONEL, Ricardo de Barros. Manual do processo coletivo. São Paulo: Revista dos Tribunais, 2002. p. 313). 


\subsection{Os controversos poderes investigatórios do Ministério Público}

Um tema ainda muito polêmico está no certame acerca dos poderes investigatórios conferidos ao Ministério Público, por essa razão, serão abaixo demonstrados os principais argumentos usados por aqueles defensores desse controverso poder de investigação, em contrapartida, os argumentos por aqueles contrários a essa interpretação.

Os embasamentos por parte do Ministério Público para corroborar tal tese estão sob os pilares constitucionais do art. $5^{\circ}$, caput $^{14}$ e parágrafo segundo, ${ }^{15}$ art. $127,{ }^{16}$ art. 129, incisos I, VI, VIII e IX; $;{ }^{17}$ e art. 144, incisos I e IV, ${ }^{18}$ todos da Carta Republicana, bem como os pilares infraconstitucionais da Lei Orgânica Nacional do Ministério Público (Lei n. 8.625/93); ${ }^{19}$ Lei Orgânica do Ministério Público da União (Lei Complementar n. 75/93) pelo art. 8 , inciso V; Código de Processo Penal Brasileiro nos arts. $4^{\circ}$ e 39, parágrafo quinto; Resolução n. 13 do CNMP, de 02 de outubro de 2006; Resolução n. 77 do Conselho Superior do Ministério Público Federal; Ato Normativo n. 314-PGJ/CPJ, de 27 de junho de 2003.

14 “Art. $5^{\circ}$ Todos são iguais perante a lei, sem distinção de qualquer natureza, garantindo-se aos brasileiros e aos estrangeiros residentes no País a inviolabilidade do direito à vida, à liberdade, à igualdade, à segurança e à propriedade $(. . .)^{\prime \prime}$

15 “Art. $5^{\circ} . \S 2^{\circ}$ - Os direitos e garantias expressos nesta Constituição não excluem outros decorrentes do regime e dos princípios por ela adotados, ou dos tratados internacionais em que a República Federativa do Brasil seja parte".

16 "Art. 127 - O Ministério Público é instituição permanente, essencial à função jurisdicional do Estado, incumbindo-lhe a defesa da ordem jurídica, do regime democrático e dos interesses sociais e individuais indisponíveis".

17 “Art. 129 - I - promover, privativamente, a ação penal pública, na forma da lei; VI - expedir notificações nos procedimentos administrativos de sua competência, requisitando informações e documentos para instruílos, na forma da lei complementar respectiva; VII - exercer o controle externo da atividade policial, na forma da lei complementar mencionada no artigo anterior; VIII - requisitar diligências investigatórias e a instauração de inquérito policial, indicados os fundamentos jurídicos de suas manifestações processuais; IX - exercer outras funções que lhe forem conferidas, desde que compatíveis com sua finalidade, sendo-lhe vedada a representação judicial e a consultoria jurídica de entidades públicas".

18 “Art. 144. A segurança pública, dever do Estado, direito e responsabilidade de todos, é exercida para a preservação da ordem pública e da incolumidade das pessoas e do patrimônio, através dos seguintes órgãos: I - polícia federal; (...) IV - polícias civis".

19 Os artigos mais utilizados para corroborar a tese em debate são os seguintes da Lei 8.625/93:

“Art. 26. No exercício de suas funções, o Ministério Público poderá: I - instaurar inquéritos civis e outras medidas e procedimentos administrativos pertinentes e, para instruí-los: a) expedir notificações para colher depoimentos ou esclarecimentos e, em caso de não comparecimento injustificado, requisitar condução coercitiva, inclusive pela Polícia Civil ou Militar, ressalvadas as prerrogativas previstas em lei; b) requisitar informações, exames periciais e documentos de autoridades federais, estaduais e municipais (...) c) promover inspeções e diligências investigatórias junto às autoridades, órgãos e entidades a que se refere a alínea anterior; (...)".

“Art. 27. Cabe ao Ministério Público exercer a defesa dos direitos assegurados nas Constituições Federal e Estadual, sempre que se cuidar de garantir-lhe o respeito: (...)"

"Parágrafo Único. No exercício das atribuições a que se refere este artigo, cabe ao Ministério Público, entre outras providências: I - receber notícias de irregularidades, petições ou reclamações de qualquer natureza, promover as apurações cabíveis que lhe sejam próprias e dar-lhes as soluções adequadas; II - zelar pela celeridade e racionalização dos procedimentos administrativos; (...)". 
Entendendo-se, destarte, que seria perfeitamente lícito ao Parquet requisitar informações e documentos a fim de instruir procedimentos administrativos instaurados no exercício de suas funções institucionais.

Isto porque, tais procedimentos destinam-se à coleta de elementos de convicção para que o Ministério Público possa identificar ou não a hipótese em que a lei exige sua iniciativa na propositura de qualquer ação pública.

Assim, os fundamentos que têm o objetivo de agasalhar a permissão investigatória feita pelo Ministério Público estão, basicamente, alicerçados nos argumentos de que o Parquet possui a titularidade da ação penal; a inexistência de um monopólio investigativo; e a teoria dos poderes implícitos.

Muito embora os julgados, não em sua totalidade, de Cortes Superiores ${ }^{20}$ tenham aceitado os poderes investigatórios do Ministério Público, cabe deixar claro que se tem deixado de analisar elementos importantes os quais não assistem razão os poderes ao Órgão conferidos como será demonstrado.

O disposto no art. 129, inciso I, da Carta Magna nada dispõe sobre qualquer autorização do Ministério Público proceder à investigação criminal diretamente, veja-se pelo art. 144, parágrafo quarto, da Constituição Federal, que dispõe: “§ $4^{\circ}$ - às polícias civis, dirigidas por delegados de polícia de carreira, incumbem, ressalvada a competência da União, as funções de polícia judiciária e a apuração de infrações penais, exceto as militares".

O que se percebe é a clara distribuição de competências na qual a Polícia Judiciária seria a incumbida a investigar, logo caberia tão somente ao Parquet requisitar diligências investigatórias, de acordo com o art. 129, inciso VIII, da Lei Maior.

Cabe deixar evidente o defendido por Manoel Gonçalves Ferreira Filho quando diferencia requisitar diligências e apurar infrações penais: "Se a Constituição dá ao Ministério Público o poder de 'requisitar a instauração de inquérito policial' é porque obviamente não lhe dá o poder de realizar a investigação criminal que se faz por meio de tal inquérito. Se o Ministério Público pudesse realizar tal inquérito, para que autorizá-lo a requisitar a instauração?" 21

Além disso, oferecer tais poderes ao Órgão é permitir a quebra do equilíbrio da própria distribuição de poderes de todo um sistema, uma vez que evidentemente estarse-ia pendendo para o lado de uma das partes de um eventual processo, cuja fiscalização não haveria, permitindo-se, inclusive, atuações perigosas, arbitrárias.

20 Habeas Corpus n. 89.837 - DF. Segunda Turma. Rel. Min. Celso de Mello. J. 20/10/2009; STJ, $5^{\text {a Turma, }}$ HC n. 13368/DF, rel. Min. Gilson Dipp, j. em 03-4-2001, DJU de 04-6-2001, p. 194, LEXSTJ 146/329; TRF $4^{\mathrm{a}}$ REGIÃO - CORREIÇÃO PARCIAL N. 2004.04.01.005131-9/RS (DJU 01.12.24, SEÇÃO 2, P. 694, J. 09.11.2004).

21 FERREIRA FILHO, Manoel Gonçalves. O poder investigatório do Ministério Público. Boletim do Instituto Manoel Pedro Pimentel, São Paulo, n. 23, 2004. p. 3. 
Igualmente, não se pode invocar a teoria dos poderes implícitos para permitir a investigação preliminar ministerial sob alegação de que poderia o Parquet oferecer denúncia sem inquérito policial, e que a Carta Republicana assegura a competência privativa para promover a ação penal juntamente com meios para alcançar tais fins.

Ora, no primeiro caso, a ausência de inquérito corresponde à desnecessidade de colheita de elementos de informação, justamente pela justa causa estar suficientemente formada. No segundo caso, os meios para alcançar os fins, ação penal, não podem ser interpretados de forma distorcida, isto é, o fim da investigação é apuração de um fato e não a ação penal, dessa forma, há o inquérito policial para colheita de materialidade e indícios de autoria. A teoria dos poderes implícitos apenas corrobora para infringência constitucional, pois não se pode haver uma interpretação ampliativa para beneficiar uma parte erroneamente dita imparcial; é aceitar e ser conivente com um desequilíbrio sistêmico.

Sendo assim, é evidente que, embora se tenha o conhecimento acerca dos poderes investigatórios do Parquet, é notório que não existem legislações explícitas abarcando a forma que essas investigações seriam feitas, possibilitando ampla margem de atuação, inclusive, arbitrariedades. ${ }^{22}$ Sendo assim, não tem o Ministério Público atribuições para promoção de investigação preliminar, uma vez que se trata da esfera exclusiva da Polícia Judiciária.

\section{Propositura (indicação, requerimento)}

O direito de proposição de provas, o segundo momento probatório, para Antonio Magalhães Gomes Filho, faz parte do direito à prova como um poder de iniciativa em relação à introdução do material probatório no processo, que seria reconhecido pelas legislações como direito não só das partes, como também de outros interessados. ${ }^{23}$

O Projeto de Lei do Senado 156 (redação de 07 de dezembro de 2010) tem em seu art. 165 que "as provas serão propostas pelas partes".

Seria, portanto, o simples fato das partes poderem requerer a produção das provas por elas trazidas em juízo com o fito de fazer valer sua tese ou de acusação, ou de defesa.

Contudo, parece haver a possibilidade, à luz do atual Código de Processo Penal, da instrução probatória por parte do magistrado como se depreende pelo art. 156:

22 Aury Lopes Jr. entende que "a legislação existente sobre o chamado controle externo da atividade policial é insatisfatória e minimalista, limitando-se a definir meros instrumentos de controle da legalidade. Permanece a lacuna e não se pode afirmar que, com a atual legislação, o MP possa assumir o controle do inquérito policial". (LOPES Jr., Aury. Direito processual penal e sua conformidade constitucional. 5. ed. Rio de Janeiro: Lumen Juris, 2010. v. 1, p. 261).

23 GOMES FILHO, Antonio Magalhães. $O$ direito à prova no processo penal. São Paulo: Revista dos Tribunais, 1997. p. 88. 
Art. 156 A prova da alegação incumbirá a quem a fizer, sendo, porém, facultado ao juiz de ofício:

I - ordenar, mesmo antes de iniciada a ação penal, a produção antecipada de provas consideradas urgentes e relevantes, observando a necessidade, adequação e proporcionalidade da medida;

II - determinar, no curso da instrução, ou antes de proferir sentença, a realização de diligências para dirimir dúvida sobre ponto relevante.

Assim, tal matéria será melhor explanada abaixo.

\subsection{A instrução probatória do juiz}

O tema da instrução probatória do juiz, relativa à imparcialidade do julgador, está inserto em um tema mais amplo que trata do sistema acusatório. Este, por sua vez, deve ser entendido para que se compreenda a impossibilidade de um julgador agir de forma instrutória em desfavor do imputado.

No sistema acusatório, tem-se "o poder de decisão da causa entregue a um órgão estatal, por sua vez distinto daquele que dispõe do poder exclusivo de iniciativa do processo". ${ }^{24}$ É também formado por normas e princípios fundamentais orientados pelo princípio acusatório. ${ }^{25}$

Pois bem, cumpre deixar cristalino que poder instrutório é diverso de investigatório. Investigação é aquela que antecede a fase processual da persecução penal, conforme já debatido quanto aos inquéritos policiais e extrapolicias. Na fase judicial, por seu turno, a quantidade e incidência de garantias processuais é muito maior.

Ademais, na fase investigatória, busca-se a construção de uma tese acusatória em que se procura identificar o fato a ser imputado. Toda a dinâmica da referida fase é pautada pela natureza investigatória e os atos são para obtenção de provas, assim, parte-se de um marco inicial e tem-se como objetivo a elaboração de uma tese investigatória; logo, os poderes das autoridades nesta fase são investigatórios.

24 PRADO, Geraldo. Sistema acusatório: a conformidade constitucional das leis processuais penais. Rio de Janeiro: Lúmen Júris, 1999. p. 112.

25 O princípio acusatório, de acordo com Geraldo Prado, pode ser entendido sob dois pontos de vista, o estático como processo de partes com direito de ação, direito de defesa e o poder jurisdicional; e o ponto de vista dinâmico relacionado às funções de cada parte e como se entrelaçam (juiz, réu, defensor, autor). Assim, é fundado na oposição entre acusação e defesa com seus respectivos direitos, deveres, ônus, faculdades, exigindo-se, portanto, um processo de partes. Nesse sentido, há a busca da acusação e da defesa conformar o juízo, que deve ser feito por um juiz constitucionalmente imparcial, é a decisão jurisdicional. Conforme defende Prado, "a real acusatoriedade depende da imparcialidade do julgador" (PRADO, Geraldo. op. cit., p. 116). Pode também tal princípio estar presente em momento pré-processual quando o titular da ação penal atuar na busca de elementos de formação da convicção judicial. 
Após a denúncia, tem-se um fato imputado. O que se realiza na segunda fase processual é a análise da veracidade da afirmação, assim, submete-se a tese acusatória a um experimento de prova. Nesse momento, não se investiga, mas faz-se instrução e os poderes concedidos ao juiz nesta fase não são investigatórios, mas instrutórios.

Ao final da persecução penal, alguns estados subjetivos podem ocorrer ao julgador, possibilitando-o concluir se a afirmação é verdadeira, momento em que será reconhecida a procedência do pedido e a sentença condenatória. $\mathrm{Ou}$ a experiência probatória tem a condição de revelar que a tese acusatória é falsa, total ou parcialmente e a solução natural seria a absolvição. O magistrado pode, por fim, chegar a uma situação de dúvida, possibilitando duas soluções: a absolvição, pelo in dubio pro reo, que seria a mais coerente; ou a persistência de dúvida que, em tese, poderia ser sanada pelo fato da provável existência de outros elementos de prova ainda não trazidos aos autos.

Nessa fase é que se insere o tema dos poderes instrutórios do juiz, cujo objetivo é dirimir a dúvida relevante. A nova prova tem a capacidade de suprir por completo a dúvida, tanto no sentido da condenação como da absolvição. Se a dúvida persistir, impõe-se a absolvição.

Nesse contexto, é indispensável explanar os tipos de sistemas processuais, quais sejam, o acusatório, o inquisitório, e o misto, e, na common law, o adversarial e o inquisitorial.

Ada Pellegrini Grinover faz uma comparação, de maneira sintética, o que distingue o modelo acusatório do inquisitório. ${ }^{26} \mathrm{O}$ sistema acusatório, teria as funções de acusar, defender e julgar atribuídas a órgãos distintos. Já no sistema inquisitório, as funções estariam reunidas e o inquisidor deve proceder espontaneamente. Nas palavras de Grinover, "é só no processo acusatório que o juízo penal é o actum trium personarum, de que falava Búlgaro, enquanto no processo inquisitório a investigação unilateral a tudo se antepõe tanto que dele disse Alacalá-Zamora não se tratar de processo genuíno, mas sim de forma autodefensiva da administração da justiça", ${ }^{27}$

Assim, no sistema inquisitório o mesmo sujeito processual que apresenta a tese acusatória, julgá-la-á. Poderá haver uma investigação policial presidida por um juiz, mas não existirá, nesse caso, um processo.

26 Para Aury Lopes Jr. e Jacinto Coutinho, a principal característica deste sistema é a premissa de que não se pode haver coincidência subjetiva entre o poder de acusar e julgar, ou seja, o órgão que apresenta a acusação não necessariamente deve ser o mesmo a julgar. Assim, a essência estaria na gestão da prova, não pode ser acusatório um sistema em que, mesmo havendo separação de funções, o juiz tenha iniciativas probatórias ex officio, pois seria difícil imaginar que o sujeito promotor da tese acusatória esteja apto a julgar com imparcialidade. (LOPES Jr., Aury. Introdução crítica ao processo penal. 5. ed. Rio de Janeiro: Lumen Juris, 2010; COUTINHO, Jacinto Nelson de Miranda. Introdução aos princípios gerais do processo penal brasileiro. Revista de Estudos Criminais, Porto Alegre: Nota Dez Editora, n. 1. 2001.)

27 GRINOVER, Ada Pellegrini. A iniciativa instrutória do juiz no processo penal acusatório. Revista Brasileira de Ciências Criminais, São Paulo: Revista dos Tribunais, a. 7, n. 27. 1999. p. 75. 
No modelo acusatório, portanto, os elementos probatórios colhidos em fase preliminar de investigação, anterior ao processo, não podem servir para a formação do convencimento do julgador se forem as únicas peças informativas apresentadas, sem ter passado pelo contraditório, ressalvadas as hipóteses de provas irrepetíveis, antecipadas, ou cautelares, de acordo com o art. 155, do Código de Processo Penal.

E, ainda, o exercício da jurisdição depende de acusação formulada por órgão diverso do juiz e todo o processo deve se desenvolver em contraditório pleno perante o juiz natural.

O sistema misto, ${ }^{28}$ por sua vez, surgiu na época da Revolução Francesa. O iluminismo destruiu as concepções continentais e passou-se a buscar uma aproximação com o modelo inglês, assim, passou-se a mesclar os dois modelos. Alguns chamam de inquisitório reformado, pois dizem que é o inquisitório com roupagem acusatória e há grande alargamento deste modelo misto no qual se encontram desde modelos muito próximos aos modelos puros até misturas mais equilibradas.

$\mathrm{Na}$ common law, conforme mencioando, existem os sistemas adversarial e o inquistorial. O modelo adversarial é aquele no qual o juiz fica de fora do duelo entre as partes, fixa apenas as regras e vela pelos seus cumprimentos, assim, os magistrados não interferem, apenas assistem ao embate processual. Há a "predominância das partes na determinação da marcha do processo e na produção das provas". ${ }^{29}$ No inquisitorial system as atividades de determinação da marcha do processo, bem como na produção de provas recaem de preferência sobre o juiz.

Entendido tais conceitos, no sistema brasileiro, conforme o art. 129, I da Carta Republicana, compete privativamente ao Ministério Público promover a ação penal pública, inferindo-se que o constituinte adotou o modelo do sistema acusatório.

O Supremo Tribunal Federal reconhece o modelo acusatório como abraçado pelo constituinte, declarando inconstitucional o art. 3 da Lei n. 9.034/95, ${ }^{30}$ por conferir ao juiz o poder de colheita de prova. ${ }^{31}$

No texto do art. 156, do Código de Processo Penal, quando trata da produção antecipada de prova, define-se a medida cautelar e a prova é colhida para se resguardar o interesse da atividade probatória.

28 Em sentido crítico pela inexistência de um sistema misto, coloca Aury Lopes Jr. que a classificação de sistema mista pecaria por insuficiência por não enfrentar "o ponto nevrálgico da questão: a identificação do núcleo fundante". (LOPES Jr., Aury. Introdução crítica ao processo penal. 5. ed. Rio de Janeiro: Lumen Juris, 2010. p. 164)

29 GRINOVER, Ada Pellegrini. A iniciativa instrutória do juiz no processo penal acusatório. Revista Brasileira de Ciências Criminais, São Paulo: Revista dos Tribunais, a. 7, n. 27. 1999. p. 72.

30 Art. $3^{\circ}$ Nas hipóteses do inciso III do art. $2^{\circ}$ desta lei, ocorrendo possibilidade de violação de sigilo preservado pela Constituição ou por lei, a diligência será realizada pessoalmente pelo juiz, adotado o mais rigoroso segredo de justiça.

31 GOMES FILHO, Antonio Magalhães. In. MOURA, Maria Thereza Rocha de Assis (Coord.) As reformas no processo penal. São Paulo: Revista dos Tribunais, 2009. p. 261. 
Nesse contexto, o "juiz pode determinar produção antecipada de provas consideradas urgentes e relevantes, a lei não contempla outra coisa senão a iniciativa judicial para a antecipação de atos tendentes à formação de provas - não de elementos de investigação-, diante do risco de desaparecimento ou deterioração das fontes de informação". 32

Quanto ao art. 212, do Código de Processo Penal, até a reforma pela Lei 11.690/08, utilizava-se o sistema presidencial no qual o juiz fazia as perguntas às partes como intermediador e, pós-reforma, não cabe mais ao magistrado tal iniciativa. Ele pergunta ao final e apenas para esclarecer dúvida que tenha remanescido. Este artigo tem inspiração nitidamente adversarial, contudo não se pode com isso dizer que o modelo do Código é o adversarial do sistema inglês.

O Projeto de Lei n. 156/09 de Código de Processo Penal tem uma clara preocupação, conforme sua própria exposição de motivos, que seria a manutenção do modelo acusatório. Há, no mencionado Projeto, que poder instrutório não é incompatível com o modelo acusatório, mas interferência na fase investigatória é incompatível.

$\mathrm{O}$ inquérito policial não mais passará pelo juiz e caberá a ele apenas analisar as medidas cautelares como restrições de direito, análise de flagrante, prisões cautelares, busca e apreensão, interceptação das comunicações telefônicas etc. Será decidido pelo juiz de garantias ${ }^{33}$ e o magistrado que enfrentar estas medidas não poderá ser o mesmo juiz da ação penal condenatória.

Os poderes instrutórios do juiz prejudicariam a imparcialidade, uma vez que o recolhimento da prova pelo magistrado acabaria por antecipar o juízo acerca

32 GOMES FILHO, Antonio Magalhães. In. MOURA, Maria Thereza Rocha de Assis (Coord.) As reformas no processo penal. São Paulo: RT, 2009. p. 261.

33 Aury Lopes Jr. já discutia em seu livro Sistemas de investigação preliminar no processo penal a existência do juiz de garantias, seria um juiz DA instrução e não DE instrução que não realizaria tarefas investigatórias ou instrutoras, "senão de garantia, como um verdadeiro garante, atuando no controle da adoção e realização das medidas restritivas de direitos fundamentais". O jurista elenca as funções do mencionado juiz: "função de garantia da liberdade pessoal e da liberdade das comunicações do sujeito passivo; função de controle da duração da investigação preliminar e da modalidade de ação penal que deverá exercer o Ministério Público; função de garantia da formação antecipada da prova no incidente probatório; função de decisão e controle do resultado da investigação preliminar na audiência preliminar". Assim, o juiz que atuou na investigação preliminar estaria prevento e não poderia presidir o processo, mesmo que tivesse decretado qualquer medida cautelar, pois sua imparcialidade estaria comprometida, logo impossibilitado de julgar. (LOPES Jr., Aury. Sistemas de investigação preliminar no processo penal. 4. ed. Rio de Janeiro: Lumen Juris, 2006. p. 265266). Na Comarca da Capital do Estado de São Paulo, tem-se a atuação deste "tipo" de juiz de garantias no Departamento de Inquérito Policial e Polícia Judiciária (DIPO). Veja-se pelo exposto de Moacir Martini de Araujo, "os persecutórios policiais na capital tramitam perante determinados juízes que não atuam no feito durante a segunda fase da persecução penal, trata-se do DIPO (Departamento de Inquérito Policial da Capital), trata-se de um verdadeiro juiz de garantias, o que só contribui a dignidade do investigado" (ARAUJO, Moacir Martini de. Mais uma amostra da crise pós-moderna vivenciada pelos poderes e instituições democráticas do brasil - breves comentários sobre a inconstitucionalidade da resolução $n$. 063/09 do conselho da justiça federal. Disponível em: <www.ibccrim.org.br>. Acessado em: 05 abr. 2011) 
dela, haveria um prévio raciocínio para justificar a busca, portanto, estaríamos diante de uma violação constitucional, todavia cabendo uma única exceção: a permissão de tais poderes à assistência do acusado. ${ }^{34}$ Assim, permitir o poder instrutório do juiz é aceitar o pensamento de um julgador inquisidor na busca da inexistente verdade real.

Há que se fazer menção aos dizeres de Geraldo Prado quando explicita "quem procura sabe ao certo o que pretende encontrar e isso, em termos de processo penal condenatório, representa uma inclinação ou tendência perigosamente comprometedora da imparcialidade do julgador". 35

Nesse sentido, o inciso I, do art. 156, do Código de Processo Penal pode ser considerado inconstitucional, pois o magistrado não pode ter qualquer poder de investigação.

Já no inciso II do mesmo artigo, em fase judicial, pode-se interpretar que o juiz não pode no curso do processo determinar, de ofício, meios de investigação, ou buscar provas, etc., mas poderia diligenciar em provas já em curso, diligências estas necessariamente obedecendo ao princípio da motivação das decisões, portanto devidamente fundamentadas.

Assim sendo, o momento de propositura da prova corresponde ao direito conferido às partes de requerer ao juiz a produção de provas sobre fatos pertinentes e relevantes para a confirmação de suas alegações. Este, de seu lado, não pode agir em busca de provas sob pena de ferir frontalmente o sistema acusatório e a própria lógica dialética do processo.

\section{Admissão}

O direito à admissão refere-se ao deferimento do requerimento de proposição das provas que sejam lícitas, pertinentes e relevantes. "A admissão ou deferimento das provas se dá por decisão judicial. Correlato à proposição de provas lícitas é o direito de exclusão das provas inadmissíveis. A inadmissibilidade é uma sanção processual que visa a impedir que provas viciadas ingressem no processo e possam influenciar, de alguma forma, o convencimento judicial", ${ }^{36}$

34 De acordo com Geraldo Prado, "segundo o princípio acusatório, não se deve encontrar aquele pertinente à investigação judicial, permitindo-se, quando muito, pela coordenação dos princípios constitucionais da justiça material e presunção de inocência, que moderadamente intervenha, durante a instrução, para, na implementação de poderes de assistência ao acusado" (PRADO, Geraldo. Sistema acusatório: a conformidade constitucional das leis processuais penais. Rio de Janeiro: Lúmen Júris, 1999. p. 129-130).

35 PRADO, Geraldo. Sistema acusatório: a conformidade constitucional das leis processuais penais. Rio de Janeiro: Lúmen Júris, 1999. p. 129.

36 BADARÓ, Gustavo H. R. Ivahy. Direito processual penal. Rio de Janeiro: Elsevier, 2008. p. 204. 
Dessa maneira, esse momento probatório se aplica ex ante nos casos em que a lei expressa e veda a determinada prova, difere-se, pois, da nulidade que se opera ex post factum.

É, segundo Antonio Magalhães Gomes Filho, "a efetiva permissão para o ingresso dos elementos pretendidos pelos interessados que caracteriza a observância do direito à prova; por isso, somente através de uma disciplina legal das hipóteses de rejeição das provas, acompanhada da exigência de decisões expressas e motivadas, e adotadas após o debate contraditório, pode estar satisfeita a garantia". ${ }^{37}$

Haveria, portanto, uma valoração prévia feita pelo legislador com o objetivo de evitar que elementos provenientes de fontes viciadas, ou meio de provas inidôneo, tenham o ingresso no processo e sejam valorados pelo magistrado na reconstrução dos fatos. É por essa razão que se faz uma formulação negativa como inadmissibilidade, proibição de prova, exclusionary rules.

A admissibilidade decorre de uma apreciação feita antecipadamente, impedindo que uma irregularidade se consume. Tenta-se de evitar o ingresso do ato processual irregular. Nesse sentido, a inadmissibilidade, "por operar em momento anterior à prática ou ao ingresso do ato no processo, impede a produção de qualquer efeito válido, aproximando-se mais da ideia da inexistência (jurídica) do ato vedado pela lei processual". ${ }^{38}$

Difere-se do plano da nulidade ${ }^{39}$ no qual paira no tocante à questão da validade e da eficácia dos atos processuais. Assim, a atividade processual deve estar de acordo com os ditames do legislador e sua observância estaria o mais próximo da participação efetiva dos interessados e da possibilidade de correção dos atos jurisdicionais. Ela é declarada depois do ato irregular ter adentrado ao processo.

Segundo Gomes Filho, a valoração prévia é mais evidente no sistema da common law, uma vez que o julgamento dos fatos estariam atrelados a cidadãos comuns,

37 GOMES FILHO, Antonio Magalhães. O direito à prova no processo penal. São Paulo: Revista dos Tribunais, 1997. p. 88.

38 GOMES FILHO, Antonio Magalhães. $O$ direito à prova no processo penal. São Paulo: Revista dos Tribunais, 1997. p. 94.

39 São atos processuais inexistentes aqueles aos quais falta, de forma absoluta, algum dos elementos exigidos pela lei; neles, o vício é de tal gravidade que sequer seria possível considerá-los como atos processuais; são na verdade, não-atos, em relação aos quais não se cogita de invalidação, pois a inexistência constitui um problema que antecede a qualquer consideração sobre a validade. Por outro lado, dentre os atos processuais imperfeitos, os atos nulos são aqueles em que a falta de adequação ao tipo legal pode levar ao reconhecimento de sua inaptidão para produzir efeitos no mundo jurídico. Nesses casos, a desconformidade pode levar ao reconhecimento da ineficácia do ato porque, ao reverso do que sucede no direito privado, a nulidade dos atos processuais não é automática, dependendo sempre seu reconhecimento de um pronunciamento judicial em que seja não somente constatada a atipicidade do ato, mas também analisados os demais pressupostos legais para a decretação da invalidade. (GRINOVER, Ada Pellegrini; SCARANCE, Antonio; GOMES FILHO, Antonio Magalhães. As nulidades no processo penal. 11. ed. São Paulo: Revista dos Tribunais, 2009. p. 18-19) 
facilmente iludidos por certas provas com valor diverso do que realmente possuem. É também encontrada tal tipo de valoração antecipada em ordenamentos de tradição continental. Exclui-se, portanto, as provas que possam levar o julgador a uma reconstrução inexata dos fatos, ou pode estar baseada em considerações estranhas à pesquisa da verdade, "como ocorre em relação à inadmissibilidade de provas cuja obtenção importe em violação de outros direitos, especialmente aqueles de natureza fundamental, inscritos na Constituição". ${ }^{40}$

Deste modo, há que se discutir acerca das provas ilícitas nesse momento probatório.

\subsection{As provas ilícitas no Processo Penal}

Quando se trata da prova ilícita, deve-se remeter à prova vedada ou proibida como um gênero que se divide em dois sub-tópicos, quais sejam a própria prova ilícita e a prova ilegítima. Essa divisão foi conceituada pelo italiano Nuvolone e trazida e implantada no Brasil por Ada Pellegrini Grinover. ${ }^{41}$

Deve-se fazer tal distinção pelo fato de ambas as provas vedadas ocorrerem em planos distintos, ou seja, a prova ilegítima tem o momento de violação na sua produção, é, pois, uma violação endoprocessual. Seu plano de discussão é o de validade podendo-se arguir a sua nulidade. Exemplo no caso da prova produzida na oitiva de uma testemunha, em que o magistrado não permite a formulação de perguntas a uma das partes, nesse caso, pode-se alegar a nulidade permitindo-se a reformulação do momento processual violado.

Nesse mesmo sentido, Walter Coelho ${ }^{42}$ afirma que a prova será ilegítima a partir do momento em que conflitar com uma norma de caráter processual, assim, teríamos uma prova à deriva do ordenamento jurídico processual e que, no momento de discordância e desrespeito ao direito instrumental, produziu-se de forma ilegítima. E Adalberto Aranha ${ }^{43}$ deixa cristalino que a ofensa ao direito quando da produção da prova, de sua introdução ao processo, ferindo uma norma processual é o caso de prova ilegítima.

A prova ilegal, de seu lado, tem o seu momento de violação anterior ao processo, isto é, ocorre na sua obtenção, é extraprocessual. Viola-se, nesse caso, um direito material, mais especificamente uma intimidade, privacidade, integridade, ou seja, um direito e garantia pessoal. Seu plano de discussão é o da existência, mais especificamente, da inexistência, pois se trataria de uma não-prova e, em havendo, sua utilização deverá

\footnotetext{
40 GOMES FILHO, Antonio Magalhães. op. cit., p. 95.

41 GRINOVER, Ada Pellegrini. Liberdades públicas e processo penal: as interceptações telefônicas. 2. ed. São Paulo: Revista dos Tribunais, 1982. p. 96-99.

42 WALTER, Coelho. Prova indiciária em matéria criminal. Porto Alegre: Sérgio Antonio Fabris Editor, 1996. p. 131.

43 ARANHA, Adalberto José Q. T. de Camargo. Da prova no processo penal. 7. ed. São Paulo: Saraiva, 2006. p. 49-52.
} 
tal prova ser extirpada, pois é constitucionalmente inadmissível. É o caso da prova obtida mediante tortura, fere-se aqui um direito e garantia fundamental e tal prova é inadmissível.

A mencionada distinção é o entendimento do Supremo Tribunal Federal corroborado pelo julgamento do HC n. 81.167/BA, cujo relator, o Ministro Gilmar Mendes, diferenciando que prova ilícita é aquela que viola norma ou princípio de direito material e prova ilegítima é aquela que ofende normas ou princípios de Direito Processual.

Portanto, quanto à distinção no plano da natureza da norma violada, segundo Luiz Francisco Avolio, ${ }^{44}$ temos a diferenciação em relação ao momento de sua transgressão: a prova ilegítima tem sua ilegalidade ocorrida no momento de sua produção no processo, já a prova ilícita pressupõe uma violação no momento da colheita da prova, anterior ou concomitante ao processo, mas sempre exterior a este processo.

As Mesas de Processo Penal da Faculdade de Direito da Universidade de São Paulo ${ }^{45}$ adotaram posições da inadmissão de qualquer prova obtida por meio ilícitos. Isso resultou em Súmulas:

Número 48 - Denominam-se ilícitas as provas colhidas com infringência a normas e princípios de direito material;

Número 49 - São processualmente inadmissíveis as provas que infringem normas e princípios constitucionais, ainda quando forem relevantes e pertinentes, e mesmo sem cominação processual expressa;

Número 50- Podem ser utilizadas no processo penal as provas ilicitamente colhidas, que beneficiem a defesa.

Nessa mesma seara da prova ilegal, há a discussão de sua possível incorporação e valoração no processo invocando a proporcionalidade ${ }^{46}$ na ótica da defesa aplicada pela doutrina alemã e discutida, hodiernamente, no Brasil, cuja consequência seria a eventual aceitação de uma prova ilegal utilizando-se do sopesamento de valores, isto é, caso a caso dever-se-ia sopesar o interesse maior que prevaleceria sobre o menor.

A doutrina majoritária, como Ada Pellegrini Grinover, Antonio Scarance, Antonio Magalhães Gomes Filho, é contundente; não se pode aceitar tal argumento, podendo acarretar sérios riscos, com ressalva da prova ilícita pro reo em que o réu poderia valer-se de uma prova ilícita para defender-se e provar sua inocência agasalhado pela

44 AVOLIO, Luiz Francisco Torquato. Provas ilicitas: interceptações telefônicas e gravações clandestinas. São Paulo: Revista dos Tribunais, 1995. p. 38-40.

45 GRINOVER, Ada Pellegrini; FERNANDES, Antonio Scarance; GOMES FILHO, Antonio Magalhães. Recursos no processo penal. 6. ed. São Paulo: Revista dos Tribunais, 2009. p. 355.

46 Cabe deixar claro que embora a doutrina entenda como sinônimos a "razoabilidade" e "proporcionalidade", existem diferenças quanto à origem e aplicação, para tanto, Virgílio Afonso da Silva aclareou esse equívoco comumente cometido pela doutrina e jurisprudência, vale a leitura do artigo O proporcional e o razoável para aprofundamento do tema (SILVA, Virgílio Afonso da. O proporcional e o razoável. Revista dos Tribunais, São Paulo, v. 798, p. 23-50, abr., 2002). 
proporcionalidade. É o exemplo de um réu que intercepta uma conversação telefônica sem autorização judicial para comprovar sua inocência.

Por outro lado, pode-se interpretar o direito fundamental da inadmissibilidade das provas obtidas por meios ilícitos (art. 5\%, inciso LVI, da Carta Magna) como sendo uma regra e não um princípio, ${ }^{47}$ dessa forma, inexistindo qualquer cláusula de exceção permitindo a admissão de uma prova ilícita, é inconstitucional afirmar que são admissíveis as provas ilícitas pro reo, defendido pela doutrina majoritária.

Nesse sentido, a denominada "prova ilícita pro reo" não se trata sequer de prova ilícita, pois estar-se-ia diante de uma excludente de ilicitude, logo, à luz do art. 23 do Código Penal, ${ }^{48}$ não haveria crime, tampouco ilicitude.

Assim sendo, a regra da inadmissibilidade das provas obtidas por meio ilícitos, não possuindo qualquer cláusula de exceção, não permite invocar a regra da proporcionalidade para que seja admitida no processo a dita "prova ilícita pro reo", ora, estaria o réu acobertado pela possibilidade de demonstrar que se tratava de uma excludente de ilicitude, por exemplo, de legítima defesa, logo constitucionalmente e processualmente permitidos.

\subsubsection{As provas ilícitas por derivação}

Deve-se, igualmente, fazer menção à prova ilícita por derivação como sendo aquela que chegou por intermédio de outra prova ilícita, ou seja, mesmo que a prova final seja lícita, se foi colhida de uma ilícita, contamina esta àquela. É o caso de uma confissão extorquida mediante tortura, em que o acusado indica onde se encontra o produto do crime, que vem a ser regularmente apreendido.

A ilicitude da obtenção da prova transmite-se às provas derivadas, que são, assim, igualmente banidas do processo. Trata-se da teoria dos frutos da árvore envenenada (fruit of poisonous tree doctrine) da Suprema Corte norte-americana.

Todavia, na jurisprudência americana, o critério dos frutos da árvore envenenada não tem levado a uma proibição absoluta, admitindo-se exceções, quais sejam, os casos de independent source e de inevitable discovery. A primeira exceção, da fonte independente, foi reconhecida pela Suprema Corte em caso de 1960, no qual um

47 A diferenciação entre regras e princípios, bem como a teoria da impossibilidade de sopesamento entre regras e regras com princípios está bem explanada nos dizeres de Virgílio Afonso da Silva (SILVA, Virgílio Afonso da. Direitos fundamentais: conteúdo essencial, restrições e eficácia. 2. ed. São Paulo: Malheiros, 2010. p. 43-56); Maurício Zanoide de Moraes (MORAES, Maurício Zanoide de. Presunção de inocência no processo penal brasileiro: análise de sua estrutura normativa para elaboração legislativa e para decisão judicial. Rio de Janeiro: Lumen Juris, 2010. p. 297-309); e Robert Alexy (ALEXY, Robert. Teoria dos direitos fundamentais. São Paulo: Malheiros, 2009).

48 "Art. 23 - Não há crime quando o agente pratica o fato: I - em estado de necessidade; II - em legítima defesa; III - em estrito cumprimento de dever legal ou no exercício regular de direito". 
acusado preso ilegalmente, teve suas impressões digitais tiradas ligando-o a um roubo pelo fato de se tratar de prova ilícita por derivação, não puderam ser usadas. Porém, em segundo julgamento, a acusação apresentou as impressões digitais contidas em arquivo do FBI, reconhecendo-se, assim, a validade da prova, pois não havia conexão com a prisão arbitrária. Era uma desconexão causal entre a prova que fundamenta a decisão e as obtidas ilicitamente. $^{49}$

A segunda exceção, da descoberta inevitável, advém de um caso de 1984, cuja Suprema Corte não considerou a aplicação da teoria dos frutos da árvore envenenada. $\mathrm{O}$ acusado havia matado uma criança e ocultado o seu corpo; foi iniciada busca com cerca de 200 voluntários, nesse tempo, o acusado confessou o paradeiro do corpo por meio de prova ilegalmente obtida. A Corte considerou ilegal a confissão, mas válida a descoberta do corpo, pois era inevitável e não teria relação com a ilegalidade. ${ }^{50}$

Essas duas exceções nas quais não se haveria a contaminação das provas pelas ilícitas, à luz da teoria da árvore dos frutos envenenados, foram adaptadas à doutrina pátria a fim de trazê-las sob a forma da Lei 11.690/08, com equívocos, conforme será demonstrado.

\subsection{As disposições processuais das provas ilícitas}

A Constituição Federal dispõe em seu art. $5^{\circ}$, inciso LVI, que são inadmissíveis, no processo, as provas obtidas por meio ilícitos, portanto, aceitá-las, é ferir uma norma constitucional. Ademais, com a nova redação do art. 157, caput, do CPP, corrobora tal entendimento dispondo que:

Art. 157. São inadmissíveis, devendo ser desentranhadas do processo, as provas ilícitas, assim entendidas as obtidas em violação a normas constitucionais ou legais.

$\S 1^{\circ}$ São também inadmissíveis as provas derivadas das ilícitas, salvo quando não evidenciado o nexo de causalidade entre umas e outras, ou quando as derivadas puderem ser obtidas por uma fonte independente das primeiras.

$\S 2^{\circ}$ Considera-se fonte independente aquela que por si só, seguindo os trâmites típicos e de praxe, próprios da investigação ou instrução criminal, seria capaz de conduzir ao fato objeto da prova.

49 GOMES FILHO, Antonio Magalhães. In: MOURA, Maria Thereza Rocha de Assis (Coord.). As reformas no processo penal. São Paulo: Revista dos Tribunais, 2009. p. 267-268; GOMES FILHO, Antonio Magalhães. O direito à prova no processo penal. São Paulo: Revista dos Tribunais, 1997. p. 108-110.

50 GOMES FILHO, Antonio Magalhães. In: MOURA, Maria Thereza Rocha de Assis (Coord.). As reformas no processo penal. São Paulo: Revista dos Tribunais, 2009. p. 267-268; GOMES FILHO, Antonio Magalhães. $O$ direito à prova no processo penal. São Paulo: Revista dos Tribunais, 1997. p. 108-110. 
$\S 3^{\circ}$ Preclusa a decisão de desentranhamento da prova declarada inadmissível, esta será inutilizada por decisão judicial, facultado às partes acompanhar o incidente.

O legislador nacional com a nova redação dada ao art. 157 e parágrafos do CPP (Lei n. 11.690/08) reconheceu a inadmissibilidade das provas derivadas da ilicitude inicial e ressalvou duas situações: "quando não evidenciado o nexo de causalidade entre umas e outras"; e "quando as derivadas puderem ser obtidas por uma fonte independente das primeiras".

Ora, quando não evidenciado o nexo de causalidade entre umas e outras é, por óbvio, a possibilidade de valer da prova, pois se não há vínculo entre ambas as provas, elas não podem ser derivadas uma da outra.

Agora, equivocou-se o legislador quando tratou do conceito de fonte independente se afastando da jurisprudência americana, pois quando utiliza do verbo "puderem ser obtidas", dá-se a entender que bastaria a simples possibilidade de que a prova venha a ser obtida por meio lícito para afastar a sua contaminação pela ilegalidade inicial.

E no parágrafo segundo do art. 157 do CPP, quando buscou definir fonte independente, equivocou-se ao dispor que seria "aquela que por si só, seguindo os trâmites típicos e de praxe, próprios da investigação ou instrução criminal, seria capaz de conduzir ao fato objeto da prova", isso abre portas para que, sob esse fundamento, toda e qualquer prova derivada de outra ilícita venha a ser convalidada. É aceitar que uma confissão mediante tortura indicando local de uma prova documental e, a partir daí, mediante um mandado judicial para busca e apreensão e com a observância de todas as formalidades, o documento é apreendido.

Nesse diapasão, a prova obtida continuaria sendo ilícita advinda da derivada, igualmente ilícita, na verdade, parece ter ocorrido uma confusão do legislador entre as exceções de fonte independente e descoberta inevitável. Dessa forma, a maneira como está redigido o parágrafo segundo do art. 157 do CPP pode ser considerada inconstitucional.

O parágrafo terceiro de mesmo artigo dispõe que, uma vez desentranhada a prova declarada inadmissível, deverá ser inutilizada por decisão judicial, logo descartaria sua possível utilização em eventual processo, como forma, por exemplo, de uma prova ilícita pro reo. ${ }^{51}$

51 Nesse caso, a inutilização das provas inadmitidas, é fator de discórdia, pois Antonio Magalhães Gomes Filho, com razão, ressalta que uma prova declarada ilícita num determinado processo possa vir a ser utilizada validamente em outro. Seria o caso de se utilizar essa prova ilícita do processo "A", mas validamente lícita no processo "B" em defesa do acusado no caso de uma prova ilícita pro reo em uma revisão criminal. Acrescenta o doutro mestre que se foi afastado proposta importante do Projeto de Lei 4.205/2001 que dispunha: Preclusa a decisão de desentranhamento da prova declarada ilícita, serão tomadas as providencias para o arquivamento sigiloso em cartório. O que seria nesse contexto muito mais plausível de 
Ademais, quando menciona o mesmo parágrafo acerca da preclusão, possibilita a interpretação de que seria viável recurso contra a completa inutilização de tais provas. É uma interpretação por analogia do art. 581, XVIII, do CPP. E, na parte final, quando faculta às partes acompanhar o incidente, deveria ser obrigatória a presença das partes, tendo em vista a garantia da autodefesa e da defesa técnica, portanto, disposição inconstitucional. ${ }^{52}$

Destarte, não se pode valer-se de provas ilícitas e expô-las ao livre convencimento de um juiz para apuração de uma verdade, vez que há indubitavelmente os direitos e garantias fundamentais da pessoa humana proibindo tal ato. De nada adiantaria princípios constitucionais e processuais penais, bem como os Direitos Humanos positivados na Carta Republicana sob a forma de Direitos e Garantias Fundamentais se não fossem seguidos, obedecidos.

Por conseguinte, as provas ilícitas são inadmissíveis pela Carta Republicana de 1988, logo não podem sofrer qualquer juízo de valor, apenas devem ser excluídas, e, portanto, desentranhadas do processo de acordo com a nova redação do art. 157 do Código de Procedimento Penal.

Cabe mencionar o Projeto de Lei do Senado n. 156/09 (última redação de 07 de dezembro de 2010) que dispõe em seus art. 166 e 167, no tocante à admissão das provas, o seguinte:

Art. 166. O juiz decidirá sobre a admissão das provas, indeferindo as vedadas pela lei e as manifestamente impertinentes, irrelevantes ou protelatórias.

Parágrafo único. Somente quanto ao estado das pessoas serão observadas as restrições à prova estabelecidas na lei civil.

Art. 167. São inadmissíveis as provas obtidas por meios ilícitos e as delas derivadas.

Parágrafo único. A prova declarada inadmissível será desentranhada dos autos e arquivada sigilosamente em cartório.

Depreende-se do PLS 156 que houve a manutenção, o conceito dos dispositivos anteriores quanto à inadmissibilidade de provas obtidas por meios ilícitos e, igualmente, as delas derivadas. A consequência decorrente dessa proibição é o

se fazer. (GOMES FILHO, Antonio Magalhães; PRADO, Geraldo; BADARÓ, Gustavo; Santos, Leandro Galuzzi dos; BOTTINI, Pierpaolo Cruz. In: MOURA, Maria Thereza Rocha de Assis (Coord.). As reformas no processo penal. São Paulo: Revista dos Tribunais, 2008.).

52 GOMES FILHO, Antonio Magalhães. In: MOURA, Maria Thereza Rocha de Assis (Coord.). As reformas no processo penal. São Paulo: Revista dos Tribunais, 2009. p. 270-271. 
desentranhamento dessas provas com o arquivamento sigiloso em cartório e não mais a inutilização delas por decisão judicial.

Percebe-se também que as exceções às provas ilícitas por derivação foram excluídas, a antiga redação dos parágrafos do art. 157, do Código de Processo Penal, poderia ter sido reformulada nos moldes corretos da doutrina e jurisprudência estadunidense, nos reais conceitos de fonte independente e descoberta inevitável. Dessa forma, melhor não permanecer um texto legislativo equivocado à dar azo a interpretações arbitrárias e maléficas.

Todavia, o momento de admissão das provas, à luz do PLS 156/09, permite que as provas inadmissíveis sejam excluídas do processo, contudo permite, igualmente, que sejam as provas "manifestamente impertinentes, irrelevantes ou protelatórias" indeferidas.

Ora, o que seriam as provas impertinentes, ou irrrelevantes? O legislador não deixou claro, pois pende-se para um juízo de valor subjetivo, nesse sentido, esperase que o magistrado, em respeito ao princípio constitucional da motivação das decisões (art. 93, IX, da Carta Magna), explicite a causa de impertinência, irrelevância, deixando cristalino, nítido todo o seu raciocínio lógico, possibilitando que a parte, eventualmente prejudicada, impugne tal decisão.

Sendo assim, tal momento probatório relativo ao direito à admissão referese ao deferimento judicial do requerimento de proposição das provas que sejam lícitas, apropriadas e essenciais. A decisão sobre quais provas poderão ser produzidas em juízo deverá ser emitida pela autoridade judiciária, quando se tratar de procedimento ordinário ou o sumário, no ato em que designar a audiência de instrução (art. 399, caput, do CPP, com a redação dada pela L. n. 11.719/08). Em se tratando de procedimento relativo aos processos da competência do Tribunal do Júri, igual providência deverá ser tomada pelo julgador, porém, em conformidade com o art. 410, do CPP, com a nova redação dada pela Lei n. 11.689/08.

\section{Produção (execução, assunção)}

É o momento no qual requerida e admitida a produção de prova, surge à parte o direito à produção da prova. Portanto, os meios de prova, em regra, devem ser produzidos em contraditório, na presença das partes e do juiz natural. "Não basta, pois o contraditório sobre $^{53}$ a prova, sendo exigido o contraditório na produção da prova.

53 Há que se fazer menção à diferenciação linguística entre contraditório sobre a prova e contraditório para a prova, isto é, no primeiro caso, existe o reconhecimento da atuação do contraditório após a formação da prova, já, no segundo caso, exige-se que as partem atuem na formação do elemento de prova. Guilherme Madeira Dezem exemplifica tal distinção aparentemente insignificante, porém de grande importância para o momento probatório de produção (DEZEM, Guilherme Madeira. Da prova penal: tipo processual, provas típicas e atípicas. Campinas, SP: Millenium, 2008. p. 90-92). 
Excepcionalmente, a prova documental não precisa ser produzida em contraditório, bastando que seja submetida a um contraditório diferido, após sua juntada aos autos". ${ }^{54}$

Segundo Antonio Magalhães Gomes Filho é “assegurar a participação dos interessados nos atos de produção (execução, assunção) da prova, o que configura, no dizer de Siracusano, um direito sobre o meio de prova. É através dessa participação, com impugnações, perguntas, críticas, e eventual oferecimento de contra-prova, que se realiza, em sua plenitude, o contraditório na instrução criminal, requisito essencial à legitimação da própria atividade jurisdicional". ${ }^{5}$

O princípio do contraditório deve ser respeitado nesse momento. Trata-se, segundo Canuto Mendes de Almeida ${ }^{56}$ da "ciência bilateral dos atos e termos processuais e possibilidade de contrariá-los". Exige-se a ação e reação da parte contrária.

Tal princípio está inserto na cláusula do devido processo legal, especificamente, sob a forma de um direito e garantia fundamental do art. $5^{\circ}$, inciso LV, da Carta Republicana aduzindo "que aos litigantes, em processo judicial ou administrativo, e aos acusados em geral são assegurados o contraditório e a ampla defesa, com os meios e recursos a ela inerentes". É um direito elencado e garantido pela Convenção Americana dos Direitos Humanos, ${ }^{57}$ o Pacto San José da Costa Rica, sob a forma de uma garantia judicial no art. $8^{\circ}$.

54 BADARÓ, Gustavo H. R. Ivahy. Direito processual penal. Rio de Janeiro: Elsevier, 2008. t. 1, p. 204.

55 GOMES FILHO, Antonio Magalhães. O direito à prova no processo penal. São Paulo: Revista dos Tribunais, 1997. p. 89.

56 Citado por Marta Saad (SAAD, Marta. O direito de defesa do inquérito policial. São Paulo: Revista dos Tribunais, 2004. p. 215).

57 A maior discussão acerca da Convenção repousa sobre o seu status hierárquico, vez que a Emenda Constitucional 45 de 2004 incluiu, na Constituição Federal de 1988, o parágrafo $3^{\circ}$ do art. $5^{\circ}$, muito embora já existisse o parágrafo $2^{\circ}$. Veja-se: Art. $5^{\circ} \xi 2^{\circ}$ - Os direitos e garantias expressos nesta Constituição não excluem outros decorrentes do regime e dos principios por ela adotados, ou dos tratados internacionais em que a República Federativa do Brasil seja parte; $\S 3^{\circ}$ Os tratados e convenções internacionais sobre direitos humanos que forem aprovados, em cada Casa do Congresso Nacional, em dois turnos, por três quintos dos votos dos respectivos membros, serão equivalentes às emendas constitucionais. Pois bem, entende uma parcela da doutrina que os tratados internacionais sobre direitos humanos anteriores à EC 45 têm a equivalência de leis ordinárias. Nesse sentido, defende Alexandre de Moraes em que os tratados ingressariam, uma vez aprovadas pelo Poder Legislativo e promulgadas pelo Presidente da República, como atos normativos infraconstitucionais, logo seriam subordinados em sua integralidade às normas constitucionais. Aduz ainda o jurista que não existe hierarquia entra as normas ordinárias de direito interno $e$ as decorrentes de atos ou tratados internacionais. A ocorrência de eventual conflito entre essas normas será resolvida ou pela aplicação do critério cronológico, devendo a norma posterior revogar a norma anterior, ou pelo princípio da especialidade (MORAES, Alexandre de. Direitos humanos fundamentais: teoria geral. 8. ed. São Paulo: Atlas, 2007. p. 316).

Essa foi a posição assumida pelo Ministro Cunha Peixoto do Supremo Tribunal Federal no julgamento do Recurso Extraordinário n. 80.004/SE (RTJ 83/809), quando em seu voto adota a igualdade de força entre normas ordinárias e tratados internacionais de direitos humanos (RTJ 83/817), embora tenha sido o voto vencido do Ministro Xavier de Albuquerque contrário à decisão (RTJ 83/813).

Uma corrente intermediária adotada pelo Ministro Sepúlveda Pertence, acerca do debate em tela, pois defende o grande jurista a existência de uma hierarquia supralegal, mas infraconstitucional, dos tratados 
Importa, nessa fase processual, grande importância do contraditório devendo-se tomar as lições de Rogério Lauria Tucci ensinando que o direito do indivíduo "à contrariedade real assume natureza indisponível, dada, precipuamente, a indisponibilidade dos interesses em conflito, de sorte a apresentar-se como autêntica expressão de sua

sobre Direitos Humanos, conforme o julgado RHC n. 79.785/RJ.

Nessa mesma seara, o Ministro Cezar Peluso em seu relatório, no julgado RE 466.343/SP, onde se debatia sobre a impossibilidade da prisão civil na alienação fiduciária em garantia, também se conceituou o tratado de direitos humanos como um direito supralegal. Assim, a norma supralegal seria apenas modificável se houvesse outra Convenção revogando a matéria da norma anterior ou se viesse uma Emenda Constitucional tratando sobre Direitos Humanos, porém, em se tratando de direitos humanos, temos a proteção via cláusula pétrea do art. 60, parágrafo $4^{\circ}$ da Carta Magna, portanto, para que essa Emenda Constitucional revogue algo do tratado versando sobre direitos humanos, deve ser matéria não tratada explicitamente nos direitos e garantias fundamentais, como por exemplo o princípio do duplo grau de jurisdição.

Uma terceira corrente começou a se firmar, inclusive, no mesmo julgado RE 466.343/SP, em que o Ministro Celso de Mello manifestou-se pela tese da hierarquia constitucional dos tratados de direitos humanos somente para os ratificados antes da EC 45 de 2004.

Os juristas Luiz Flávio Gomes e Valério de Oliveira Mazzuoli defendem que os tratados de direitos humanos ratificados pelo Brasil têm índole e nível constitucionais, quer sejam anteriores ou posteriores à EC 45/2004 (GOMES, Luiz Flávio; MAZZUOLI, Valério de Oliveira. Comentários à convenção americana sobre direitos humanos: Pacto de San José da Costa Rica. 2. ed. São Paulo: Revista dos Tribunais, 2009. v. 4, p. 16). Ainda concluem que todos os tratados que formam o "corpus" juris convencional dos direitos humanos de que um Estado é parte servem como paradigma ao controle de convencionalidade das normas infraconstitucionais, com as especificações feitas acima: a) tratados de direitos humanos internalizados com "quorum" qualificado (equivalentes às emendas constitucionais) são paradigma do controle concentrado (para além, obviamente, do controle "difuso"), cabendo, v.g., uma ADIn no STF a fim de invalidar norma infraconstitucional incompativel com eles; b) tratados de direitos humanos que têm apenas "status de norma constitucional" (não sendo equivalentes às emendas constitucionais, posto que não aprovados pela maioria qualificada do art. $\left.5^{\circ}, \S 3^{\circ}\right)$ são paradigma apenas do controle "difuso" de convencionalidade.

A jurista Flávia Piovesan, adotando essa mesma conduta, aduz que nos tratados de proteção aos direitos humanos ratificados anteriormente à Emenda Constitucional n. 45 de 2004 apenas não teriam passado pela formalidade exigida, ou seja, embora tenham ultrapassado o quorum de três quintos dos membros da Casa, não foram aprovados em dois turnos, sendo apenas em um torno de votação. Dessa forma, por força do parágrafo $2^{\circ}$ do art. $5^{\circ}$ da Carta Maior, defende que todos os tratados de direitos humanos, independentemente do "quorum" de sua aprovação, são materialmente constitucionais, compondo o bloco de constitucionalidade (PIOVESAN, Flávia. Temas de Direitos Humanos. 3. ed. São Paulo: Saraiva, 2009. p. 19-20). Sua tese é corroborada com quatro grandes argumentos: a) a interpretação sistemática da Constituição, de forma a dialogar os $\$ \xi 2^{\circ}$ e $3^{\circ}$ do art. $5^{\circ}$, já que o último não revogou o primeiro, mas deve, ao revés, ser interpretado à luz do sistema constitucional; b) a lógica e racionalidade material que devem orientar a hermenêutica dos direitos humanos; c) a necessidade de evitar interpretações que apontem a agudos anacronismos da ordem jurídica; e d) a teoria geral da recepção do Direito brasileiro.

Dessa explicação se infere que enquanto os tratados versados sobre direitos humanos forem ratificados à luz da EC 45/2004, portanto, após o advento dessa emenda, serão eles materialmente e formalmente constitucionais, este último requisito devido à necessidade de se passar por crivo de um três quintos dos votos da Casa em dois turnos, já os tratados relativos aos direitos humanos aprovados anteriormente à emenda referida terão a natureza materialmente constitucional, pois não havia previsto o iter do parágrafo $3^{\circ}$ do art. $5^{\circ}$ da Constituição Federal de 1988. O posicionamento mais adequado, quanto ao status hierárquico do tratado de direitos humanos anterior à Emenda Constitucional de 45/04, está na consideração da Convenção Americana de Direitos Humanos como sendo uma norma, no mínimo, materialmente constitucional, mas não formalmente constitucional, uma vez que o parágrafo $3^{\circ}$ do art. $5^{\circ}$ da Carta Magna incluiu procedimento a ser seguido para que um tratado ou convenção versando sobre de direitos humanos tenha força equivalente às emendas constitucionais. 
liberdade jurídica, a saber: conferindo-se ao acusado o direito à jurisdição penal, exercido por meio de um processo no qual the assegure a ampla defesa, sobretudo em razão da atividade marcantemente contraditória, efetivada por órgão técnico". ${ }^{58}$

Ada Pellegrini Grinover, citando Barbosa Moreira, ministra que "a garantia do contraditório significa, antes de mais nada, que ambas as partes há de conceder iguais oportunidades de pleitear a produção de provas (...). Significa, a seguir, que não deve haver disparidade de critérios no deferimento ou indeferimento dessas provas pelo órgão jurisdicional. Também significa que as partes terão as mesmas possibilidades de participar dos atos probatórios e de pronunciar-se sobre seus resultados". ${ }^{59}$ Assim, o contraditório tem grande importância no momento de produção de provas, pois se trata de uma atividade que busca a constituição do material probatório a ser utilizado pelo órgão jurisdicional julgador na formação de seu convencimento.

Todavia, cumpre esclarecer que existem situações as quais não se pode esperar o curso normal do processo sob o risco de se ter determinada prova deteriorada, por essa razão, passa-se a se valer da antecipação das provas. Nessa condição, pode-se haver o contraditório diferido, que permitem às partes no curso do processo analisar e discutir acerca das provas previamente produzidas.

À vista disso, admitida a prova, o momento seguinte seria o direito à sua produção; nesse sentido, deve-se se observar a plena aplicação do princípio do contraditório a fim de dar validade às provas que serão apresentadas ao órgão jurisdicional julgador e serão os meios pelos quais se buscará o convencimento do juiz.

\section{Valoração}

O último e importante momento probatório, a valoração das provas é o momento no qual haverá a avaliação da idoneidade dos elementos de prova, seria uma apreciação isolada sobre a aptidão de cada elemento obtido para servir de fundamento ao convencimento judicial, é o devido respeito dos momentos anteriormente explicitados. Ocorre anteriormente ao outro submomento, de igual importância, que "seriam as operações inferenciais necessárias à determinação do enunciado factual que será adotado como premissa do raciocínio decisório final". ${ }^{60}$

Conforme Gustavo Badaró, “de nada adiantaria o direito de investigar, requerer, ter admitida e produzida a prova, se no momento culminante do processo, o juiz

58 TUCCI, Rogério Lauria. Direitos e garantias individuais no processo penal brasileiro. 3. ed. São Paulo: Revista dos Tribunais, 2009. p. 104-105.

59 GRINOVER, Ada Pellegrini. O conteúdo da garantia do contraditório. In: Novas tendências do direito processual. Rio de Janeiro: Forense Universitária, 1990. p. 20-21.

60 GOMES FILHO, Antonio Magalhães. A motivação das decisões penais. São Paulo: Revista dos Tribunais, 2001. p. 157. 
pudesse simplesmente, ignorar a prova. Toda a prova produzida deve ser valorada pelo juiz. É óbvio que o juiz não é obrigado a acolher a prova, mas considerá-la insuficiente para convencê-lo da ocorrência de determinado fato". ${ }^{61}$ Não poderia, portanto, o juiz ignorar a prova produzida e deve, se produzida, ser valorada. É nesse ponto que a fundamentação da sentença teria um papel essencial para aferição do respeito do direito à prova.

Para Marina Gascón Anellán, a valoração das provas é o juízo de aceitabilidade dos resultados produzidos pelos meios de prova. Consiste, especificamente, na verificação dos enunciados fáticos introduzidos no processo por intermédio dos meios de prova, assim, como no reconhecimento dos mesmos por um determinado valor ou peso na formação da convicção do julgador sobre os fatos que são considerados. ${ }^{62}$

Cabe ressaltar que foram criados modelos de valoração dos fatos, que seriam produzidos pelas provas, assim, existe uma evolução do modelo probatório contemporâneo a fim de que sejam valoradas as provas de acordo com o procedimento institucionalizado em cada período. Nesse sentido, pode-se citar os modelos de valoração da prova legal ou taxada, o da íntima convicção e o modelo do livre convencimento, explanados no próximo capítulo.

$\mathrm{O}$ último momento probatório, portanto, seria aquele em que se procede a valoração das provas trazidas em juízo. Toda prova produzida deve ser valorada pelo juiz, logo ao término da instrução, isto é, após os debates orais em audiência, passando-se à fase decisória do processo, o julgador, ao fundamentar a sentença, deve pronunciar-se acerca de todas as provas produzidas, acolhendo aquelas que firmarão o seu convencimento em prejuízo das outras que serão desconsideradas.

É a valoração, portanto, não só uma fase conclusiva de todo o procedimento probatório, respeitados os momentos probatórios, como também um ponto de observação privilegiado para se apreciar a efetividade do direito das partes a influir no acertamento dos fatos. É trazer para o concreto e assegurar o efeito da atividade probatória, ou seja, fazer com que sejam as provas avaliadas pelo juiz da decisão.

Igualmente é, nesse momento probatório, consistir para que se tornem reais os efeitos das regras de legalidade na obtenção e incorporação das provas no processo, diante da proibição imposta pelo julgador de se avaliar os elementos introduzidos com violações à normais constitucionais ou legais. Seria a concretização do direito à exclusão, que seria a não utilização, na decisão, dos dados resultantes de violações às regras legais.

Em suma, as atividades probatórias vão ao encontro do momento culminante que seria a valoração das provas dos elementos recolhidos. As provas por si só não tem

BADARÓ, Gustavo H. R. Ivahy. Direito processual penal. Rio de Janeiro: Elsevier, 2008. p. 204.

62 GASCÓN ABELLÁN, Marina. Los hechos en el derecho: bases argumentales de la prueba. Madrid: Marcial Pons, 1999. p. 157. (tradução livre) 
valor, deve-se haver um conjunto delas para então servir de fundamento à conclusão final de acordo com que elas poderão resultar. Dessa forma, são necessárias a seleção, a crítica, ou a rejeição dos materiais produzidos com o fim de se extrair uma convicção a respeito dos fatos investigados. Haverá nesse instante, a transformação, ou não, dos dados objetivos resultantes dos procedimentos probatórios em uma crença acerca da veracidade ou falsidade das proposições de fato afirmadas pelas partes.

Por conseguinte, a valoração da prova deve conceber-se como uma atividade racional consistente na eleição da hipótese mais provável entre as diversas reconstruções possíveis dos fatos. ${ }^{63}$ Trata-se de um conjunto de aferições intelectuais que têm como escopo conhecer o mérito da convicção que pode resultar das provas trazidas ao processo.

\section{Conclusão}

Pelo exaurido, para que a prova seja devidamente valorada pelo magistrado, deve passar pelos momentos probatórios, isto é, uma série de procedimentos legais para que a prova possa ter sua confiabilidade máxima com o fito de se extrair uma convicção a respeito dos fatos investigados. Foram os momentos analisados: a investigação, a propositura, a admissão, a produção, e a valoração.

$\mathrm{Na}$ investigação, buscam-se os elementos informativos necessários para formar o conteúdo probatório suficiente a fim de embasar uma ação penal. As investigações preliminares se dão por meio não só do inquérito policial, como também extrapoliciais, por exemplo, comissões parlamentares de inquérito, entre outras formas já analisadas.

Na propositura, é um momento no qual se visa à introdução do material probatório no processo, portanto, as partes requerem ao magistrado a produção das provas sobre fatos pertinentes e relevantes. É um momento no qual se discute a instrução probatória do juiz, se ocorreria o ferimento de sua imparcialidade ou não.

$\mathrm{Na}$ admissão, é o próprio deferimento das provas a serem produzidas por meio de uma decisão judicial. É um direito à exclusão das provas não de acordo com a legislação vigente, em outras palavras, é a exclusão das provas inadmissíveis impedindo que ingressem no processo e influenciem no convencimento judicial. É uma prévia valoração legal na qual o magistrado decide se cabe a inclusão ou não da prova ao processo e, para tanto, há disposições constitucionais e processuais regulando tal proibição.

Na produção, é o momento após a requisição e admissão das provas. Deve a prova ser produzida à luz do princípio do contraditório para que seja devidamente incorporada no processo, com ressalva nos caso de contraditório diferido.

63 GASCÓN ABELLÁN, Marina. Los hechos en el derecho: bases argumentales de la prueba. Madrid: Marcial Pons, 1999. p 161. (tradução livre) 
Por fim, na valoração, haverá o estudo final acerca da idoneidade dos elementos de prova; é a apreciação isolada sobre a aptidão de cada elemento obtido para servir de fundamento ao convencimento judicial. É, dessa forma, o momento que representa o devido respeito aos momentos anteriores mencionados.

Nesse momento, é o direito de não se ter a prova ignorada, mas, sim, valorada a ponto de influenciar no convencimento do magistrado, é o juízo de aceitabilidade dos resultados produzidos pelos meios de prova, que está concebido por uma atividade racional consistente na eleição da hipótese mais provável entre as diversas reconstruções possíveis dos fatos.

Dessa forma, as regras probatórias nada mais seriam que normas de garantia que decorreriam dos preceitos constitucionais, fornecendo o caráter controlável da decisão dos fatos, consequentemente, afastam a liberdade indiscriminada do juiz que poderia dar ensejo a julgamentos estritamente subjetivos, ideológicos ou emotivos.

É, pois, o devido respeito à legalidade probatória composta não pela disciplina da admissão e produção do material probatório, com também como o estabelecimento de limites legais à própria valoração com o fito de se evitar julgamentos subjetivos e arbitrários acerca dos fatos.

São Paulo, 01 de outubro de 2011.

\section{Referências}

ALEXY, Robert. Teoria dos direitos fundamentais. São Paulo: Malheiros, 2009.

ARANHA, Adalberto José Q. T. de Camargo. Da prova no processo penal. 7. ed. São Paulo: Saraiva, 2006.

ARAUJO, Moacir Martini de. Mais uma amostra da crise pós-moderna vivenciada pelos poderes e instituições democráticas do Brasil: breves comentários sobre a inconstitucionalidade da resolução n. 063/09 do conselho da justiça federal. Disponível em: <www.ibccrim.org.br>. Acessado em: 05 abr. 2011.

AVOLIO, Luiz Francisco Torquato. Provas Ilícitas: interceptações telefônicas e gravações clandestinas. São Paulo: Revista dos Tribunais, 1995.

BADARÓ, Gustavo H. R. Ivahy. Direito processual penal. Rio de Janeiro: Elsevier, 2008. t. 1.

COELHO, Walter. Prova indiciária em matéria criminal. Porto Alegre: Sérgio Antonio Fabris Editor, 1996.

COUTINHO, Jacinto Nelson de Miranda. Introdução aos princípios gerais do processo penal brasileiro. Revista de Estudos Criminais, Porto Alegre: Nota Dez Editora, n. 1. 2001. 
DEZEM, Guilherme Madeira. Da prova penal: tipo processual, provas típicas e atípicas. Campinas, SP: Millenium, 2008.

FERREIRA FILHO, Manoel Gonçalves. O poder investigatório do Ministério Público. Boletim do Instituto Manoel Pedro Pimentel, São Paulo, n. 23, 2004.

GASCÓN ABELLÁN, Marina. Los hechos en el derecho: bases argumentales de la prueba. Madrid: Marcial Pons, 1999.

GOMES FILHO, Antonio Magalhães. A motivação das decisões penais. São Paulo: Revista dos Tribunais, 2001.

GOMES FILHO, Antonio Magalhães. O direito à prova no processo penal. São Paulo: Revista dos Tribunais, 1997.

GOMES FILHO, Antonio Magalhães. O livre convencimento do juiz no projeto de código e processo penal: primeiras anotações. Boletim IBCCRIM, São Paulo, ano 17, n. 200, p. 08-09, julho 2009.

GOMES, Rodrigo Carneiro. O inquérito policial na investigação de parlamentar. Disponível em: $<$ www.ibccrim.org.br>. Acesso em: 05 abr. 2011.

GRINOVER, Ada Pellegrini. A iniciativa instrutória do juiz no processo penal acusatório. Revista Brasileira de Ciências Criminais, São Paulo: Revista dos Tribunais, a. 7, n. 27. 1999.

GRINOVER, Ada Pellegrini. Liberdades públicas e processo penal: as interceptações telefônicas. 2. ed. São Paulo: Revista dos Tribunais, 1982.

GRINOVER, Ada Pellegrini. O conteúdo da garantia do contraditório. In: Novas tendências do Direito Processual, Rio de Janeiro: Forense Universitária, 1990.

GRINOVER, Ada Pellegrini; FERNANDES, Antonio Scarance; GOMES FILHO, Antonio Magalhães. Recursos no Processo Penal. 6. ed. São Paulo: Revista dos Tribunais, 2009.

GRINOVER, Ada Pellegrini; SCARANCE, Antonio; GOMES FILHO, Antonio Magalhães. As nulidades no processo penal. 11. ed. São Paulo: Revista dos Tribunais, 2009.

HORCAIO, Ivan. Dicionário Jurídico referenciado. São Paulo: Primeira Impressão, 2006.

LEONEL, Ricardo de Barros. Manual do processo coletivo. São Paulo: Revista dos Tribunais, 2002.

LOPES Jr., Aury. Direito processual penal e sua conformidade constitucional. 5. ed. Rio de Janeiro: Lumen Juris, 2010. v. 1.

LOPES Jr., Aury. Sistemas de investigação preliminar no processo penal. 4. ed. Rio de Janeiro: Lumen Juris, 2006.

MAZZILLI, Hugo Nigro. A defesa dos interesses difusos em juizo. 22. ed. São Paulo: Saraiva, 2009. MIRABETE, Julio Fabrini. Processo penal. 18. ed. São Paulo: Atlas, 2008. 
MORAES, Maurício Zanoide de. Presunção de inocência no processo penal brasileiro: análise de sua estrutura normativa para elaboração legislativa e para decisão judicial. Rio de Janeiro: Lumen Juris, 2010.

MOURA, Maria Thereza Rocha de Assis (Coord.). As reformas no processo penal. São Paulo: Revista dos Tribunais, 2009.

PRADO, Geraldo. Sistema acusatório: a conformidade constitucional das leis processuais penais. Rio de Janeiro: Lúmen Júris, 1999.

SAAD, Marta. O direito de defesa do inquérito policial. São Paulo: Revista dos Tribunais, 2004.

SILVA, Virgílio Afonso da. Direitos fundamentais: conteúdo essencial, restrições e eficácia. 2. ed. São Paulo: Malheiros, 2010.

SILVA, Virgílio Afonso da. O proporcional e o razoável. Revista dos Tribunais, São Paulo, v. 798, p. 23-50, abr., 2002.

TUCCI, Rogério Lauria. Direitos e garantias individuais no processo penal brasileiro. 3. ed. São Paulo: Revista dos Tribunais, 2009.

VILARES, Fernanda Regina. A reserva de jurisdição no processo penal: dos reflexos no inquérito parlamentar. 2010. Dissertação (Mestrado) - Faculdade de Direito. Universidade de São Paulo, São Paulo. 